\title{
Level of Acceptance of the Community and Industry to the $K+12$ Senior High School Curriculum in Selected Municipalities of Bulacan, Philippines
}

\author{
Marilyn S. De leon ${ }^{1}$, Editha N. De Regla ${ }^{2}$ and Edwin A. Estrella ${ }^{3}$ \\ ${ }^{1,2,3}$ Bulacan State University, City of Malolos Bulacan, Philippines, Philippines, 3000
}

\begin{abstract}
Background/Objectives: This paper examines the Level of Acceptance of the parents and distinct industries from selected municipalities in the province of Bulacan, to the proposed Senior High School Curriculum, identifies which factor greatly influence the acceptance of the proposed curriculum. Methods/Statistical analysis: The 12-item self-constructed survey questionnaire was developed and validated by the researchers. The parents which represent the community have shown a result of "neutral/undecided" in four areas: family finances, $\mathrm{K}+12$ awareness, government resources, and teacher preparedness. Findings: It simply means that the government which promotes this educational reform is lacking of information dissemination program to the community, particularly to the parents. On the contrary, all factors being presented to the industry representatives have shown a result of "accepted".Improvements/Applications: It shows that the industry practitioners are somehow knowledgeable to this program of government in education. In addition, based on the study conducted, the community/parents have expressed interest in the inclusion of technical-vocational competencies such as commercial cooking, food and beverage service and automotive repairs and services and employability of the future graduates in the Senior High School program.
\end{abstract}

\section{Index Terms}

Level of Acceptance, Employability, Preparedness, Awareness

\footnotetext{
Corresponding author : Marilyn S. De leon

emnderegla@yahoo.com

- Manuscript received July 28, 2017.

- Revised August 14, 2017; Accepted September 1, 2017.

- Date of publication September 30, 2017

(c) The Academic Society of Convergence Science Inc.

2546-1583 (c) 2017 IJEMR. Personal use is permitted, but republication/redistribution requires IJEMR permission.
} 


\section{INTRODUCTION}

In our country, one of the most controversial issues in the field of education now is the implementation of the $\mathrm{K}+12$ of the Department of Education. Starting SY 2011-2012 [2], Kindergarten level has been offered to all public elementary schools nationwide and in the beginning of SY 2012-2013, the first batch of Grade 7 in public and private high schools has been using the new curriculum prescribed by department. According to the Department of Education, the major reason of this educational reform is that, the current Philippine educational system is not functional enough to produce productive and responsible citizens equipped with the essential competencies and skills for both lifelong learning and employment.

It is evident that the additional two years in the curriculum will be additional costs which will be incurred by both government and families. In return, an enhanced curriculum will decongest academic workload, giving students more time to master competencies and skills as well as time for other learning opportunities beyond the classroom, thus allowing for a more holistic development. Also, graduates will possess competencies and skills relevant to the job market. The senior high school curriculum will be designed to adjust and meet the fast-changing demands of society to prepare graduates with skills essential for the world of work (DepEd 2010).

\section{RESEARCH MODEL}

The research model in this paper suggests that six (6) input variables impact the level of acceptance perceived by parents and industry to the proposed $\mathrm{K}+12$ program of DepEd. These factors are six underlying independent variables, namely: Family Finances, K+12 Awareness, Government Resources, Teacher Preparedness, Technical-Vocational

Competencies and Employability

\section{RESEARCH RESULTS}

The 12-item self-constructed survey questionnaire was developed and validated by the researchers to assess the level of acceptance of the community and the industry to the proposed $\mathrm{K}+12$ Senior High School Curriculum of the Department of Education in selected municipalities of Bulacan.

The content validation of the instrument was facilitated by one of the professors in Bulacan State University-Graduate School. The survey questionnaire was focused on the factors influencing the level of acceptance of the community and industries to the proposed $\mathrm{K}+12$ curriculum. The factors were:
A. Family Finances
B. K+12 Awareness
C. Government Resources (classrooms, tools, equipments, supplies, etc.)
D. Teacher Preparedness
E. Technical-Vocational Competencies
F. Employability

The five-point Likert Scale was used in answering the survey questionnaire stated as:

5- Strongly Accepted

4- Accepted

3- Neutral/Undecided

2- Not Accepted

1- Strongly Not Accepted

The tables below show the responses of the respondents:

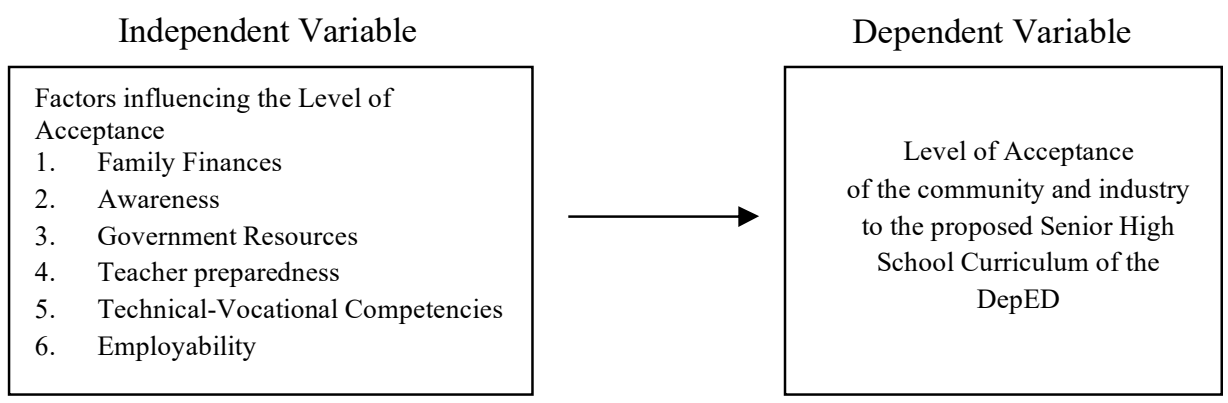

Fig. 1. Conceptual model of factors influencing level of acceptance of the community and industry to the proposed Senior High School Curriculum of the Department of Education model of factors influencing level of acceptance of the community and industry to the proposed Senior High School Curriculum of the Department of Education. 
Table 1. FAMILY FINANCES

\begin{tabular}{|c|c|c|c|c|}
\hline & \multicolumn{2}{|c|}{ Community } & \multicolumn{2}{|c|}{ Industry } \\
\hline A. Family Finances & $\mathrm{M}$ & DV & $\mathrm{M}$ & DV \\
\hline $\begin{array}{ll}\text { 1. } & \mathrm{K}+12 \text { Program is an } \\
\text { additional expense of } \\
\text { the family for basic } \\
\text { education }\end{array}$ & 4.26 & S.A. & 3.96 & A. \\
\hline $\begin{array}{ll}\text { 2. } & \text { The family has } \\
\text { sufficient budget to } \\
\text { support the additional } \\
\text { two years }\end{array}$ & 2.58 & $\mathrm{~N} / \mathrm{U}$ & 3.24 & $\mathrm{~N} / \mathrm{U}$ \\
\hline Average Weighted Mean & 3.42 & $\mathrm{~N} / \mathrm{U}$ & 3.6 & $\mathrm{~A}$ \\
\hline
\end{tabular}

As shown in table 1, the average weighted mean of 3.42 from the community sector is nearer to 3 than 4 . Therefore the equivalent category of 3.42 is "Neutral/Undecided". From this result, it revealed that the community respondents are neutral/undecided to the additional expenses and budget to support the additional two years of education. While for the industry sector, the average weighted mean of 3.6 is nearer to 4 than 3 and the equivalent category of 3.6 is "Accepted". The industry respondents accepted or they were fully aware that the $\mathrm{K}+12$ program is an additional budget for the family finances.

But for Calingasan (2012) [1], who explained that "while parents may look at this as extended expense i.e., paying tuition for another 2 years in high school, definitely this will mean that they will graduate late (by present reference point), but on another perspective, will mean that they will be more mature when they enter college, or that they will be ready for work

Table 2. $\mathrm{K}+12$ AWARENESS

\begin{tabular}{|c|c|c|c|c|c|}
\hline \multirow{2}{*}{\multicolumn{2}{|c|}{ B. K+12 Awareness }} & \multicolumn{2}{|c|}{ Community } & \multicolumn{2}{|c|}{ Industry } \\
\hline & & \multirow{2}{*}{3.24} & \multirow{2}{*}{$\mathrm{N} / \mathrm{U}$} & \multirow{2}{*}{3.4} & \multirow{3}{*}{$\begin{array}{l}\mathrm{N} / \mathrm{U} \\
\mathrm{N} / \mathrm{U}\end{array}$} \\
\hline 1 & $\begin{array}{l}\text { The community is } \\
\text { aware of the } \mathrm{K}+12 \\
\text { Program }\end{array}$ & & & & \\
\hline 2. & $\begin{array}{l}\text { The community is } \\
\text { aware of the technical } \\
\text { - vocational education } \\
\text { in the Senior High } \\
\text { School of the } K+12 \\
\text { Program }\end{array}$ & 2.6 & N.A. & 3.38 & \\
\hline Average & Veighted Mean & 2.92 & $\mathrm{~N} / \mathrm{U}$ & 3.6 & $\mathrm{~A}$ \\
\hline
\end{tabular}

As shown in table 2, the average weighted mean of 2.92 from the community sector is nearer to 3 than 2 . Therefore the equivalent category of 2.92 is "Neutral/Undecided". ," From this result, it simply means that the government which promotes this educational reform is lacking of information dissemination program to the community, particularly to the parents. The parents were not fully aware of the nature and implementation of the $\mathrm{K}+12$ program.

The average weighted mean of 3.6 from the industry sector is nearer to 4 than 3 . Therefore the equivalent category of 3.6 is "Accepted". The industry respondents accept the statements regarding $\mathrm{K}+12$ awareness. It means they are aware on the nature and implementation of the $\mathrm{K}+12$ program.

Table 3. GOVERNMENT RESOURCES

\begin{tabular}{c|c|c|c|c}
\hline \hline & \multicolumn{2}{|c|}{ Community } & \multicolumn{2}{|c}{ Industry } \\
\hline $\begin{array}{l}\text { C. Government Resources } \\
\text { (Classrooms, Tools, Equipment, } \\
\text { Supplies, etc.) }\end{array}$ & & & & \\
\hline $\begin{array}{c}\text { The government has } \\
\text { allotted enough budget in } \\
\text { the implementation of the } \\
\text { additional two years in } \\
\text { the basic education. }\end{array}$ & 3.26 & $\mathrm{~N} / \mathrm{U}$ & 3.6 & $\mathrm{~A}$ \\
\hline \hline
\end{tabular}

As shown in table 3, the weighted mean of 3.26 from the community sector is nearer to 3 than 4 . Therefore the equivalent category of 3.26 is "Neutral/Undecided". The community or the parents are not aware or do not have any idea if the government has allotted enough budget in the implementation of the additional two years in the basic education.

While for industry sector, the weighted mean of 3.6 is nearer to 4 than 3 . Therefore the equivalent category of 3.6 is "Accepted", which means that the industry respondents accepted the statement or aware and have idea that the government has allotted enough budget in the implementation of the additional two years in the basic education.

Table 4. TEACHER PREPAREDNESS

\begin{tabular}{|c|c|c|c|c|}
\hline & \multicolumn{2}{|c|}{ Community } & \multicolumn{2}{|c|}{ Industry } \\
\hline D. Teacher Preparedness & & & & \\
\hline $\begin{array}{l}\text { 1. The Department of } \\
\text { Education has been } \\
\text { continuously } \\
\text { conducting training for } \\
\text { the teachers who will } \\
\text { be involved in the } \\
\text { delivery of } \mathrm{K}+12 \\
\text { Program, specifically } \\
\text { in the Senior High } \\
\text { school. }\end{array}$ & 3.54 & $\mathrm{~A}$ & 3.6 & $\mathrm{~A}$ \\
\hline \multirow[t]{2}{*}{$\begin{array}{l}\text { 2. The teacher will } \\
\text { undergo TESDA } \\
\text { examination } \\
\text { certification }\end{array}$} & 3.14 & $\mathrm{~N} / \mathrm{U}$ & 3.44 & $\mathrm{~N} / \mathrm{U}$ \\
\hline & 3.44 & $\mathrm{~N} / \mathrm{U}$ & 3.52 & $\mathrm{~A}$ \\
\hline
\end{tabular}

As shown in table 4, it revealed the average weighted mean of 3.44 for the community sector is nearer to 3 than 4 . Therefore the equivalent category of 3.44 is "Neutral/Undecided" which means that the community is not aware or no idea if the teachers are prepared and attended training for the delivery of the $\mathrm{K}+12$ program.

While the average weighted mean of 3.52 from the industry sector is nearer to 4 than 3 . Therefore the equivalent category of 3.52 is "Accepted". The industry respondents are aware to the teacher's preparedness who will deliver the $\mathrm{K}+12$ program. 
Table 5. TeChniCAL-Vocational COMPETENCIES

\begin{tabular}{|c|c|c|c|c|}
\hline \multirow{2}{*}{$\begin{array}{l}\text { E. Technical-Vocational } \\
\text { competencies }\end{array}$} & \multicolumn{2}{|c|}{ Community } & \multicolumn{2}{|c|}{ Industry } \\
\hline & & & & \\
\hline $\begin{array}{l}\text { 1. The students will learn } \\
\text { the competencies in the } \\
\text { technical-vocational } \\
\text { courses such as: a. } \\
\text { Commercial Cooking; b. } \\
\text { food and Beverage } \\
\text { Services; c. Automotive } \\
\text { repairs and services. }\end{array}$ & 3.9 & A & 4.3 & $\mathrm{~A}$ \\
\hline
\end{tabular}

As shown in table 5, the weighted mean of 3.9 from the community sector is nearer to 4 than 3 and the equivalent category of 3.9 is "Accepted". It is the same with the computed weighted mean of 4.3 from the industries sector which is nearer to 4 than 5 with the equivalent category also of "Accepted".

DepEd says that $\mathrm{K}+12$ program will improve the chances for youth employment [4] as it is aimed to improve technical-vocational skills through focusing on arts, aquaculture and agriculture, among others. Both the community and industry respondents accepted that the $\mathrm{K}+12$ program of the government particularly the technical-vocational strand will improve the competencies of the students and will give them the chance to be employed and have jobs even without a college degree.

Table 6. EMPLOYABILITY

\begin{tabular}{c|l|l|l|l}
\hline \hline & \multicolumn{2}{|c|}{ Community } & \multicolumn{2}{|c}{ Industry } \\
\hline F.Employability & & & & \\
\hline $1 . \quad \begin{array}{l}\text { The students undergo } \\
\text { On-the-job training to } \\
\text { apply the learned } \\
\text { competencies from the } \\
\text { school. }\end{array}$ & 4.02 & $\mathrm{~A}$ & 4.3 & $\mathrm{~A}$ \\
\hline $\begin{array}{l}\text { The graduates are } \\
\text { equipped with the skills } \\
\text { needed in the food and } \\
\text { automotive industry } \\
\text { sector. }\end{array}$ & 3.3 & $\mathrm{~N} / \mathrm{U}$ & 4.2 & $\mathrm{~A}$ \\
\hline $\begin{array}{l}\text { The graduates are } \\
\text { equipped with the skills } \\
\text { needed in the food and } \\
\text { automotive industry } \\
\text { sector. }\end{array}$ & 3.3 & $\mathrm{~N} / \mathrm{U}$ & 4.2 & $\mathrm{~A}$ \\
\hline $\begin{array}{l}\text { Private and public } \\
\text { schools which are } \\
\text { involved in the } \\
\text { implementation of the } \\
\text { Senior High School will } \\
\text { establish partnership } \\
\text { with the local food and } \\
\text { automotive industries for } \\
\text { possible employment of } \\
\text { SHS graduates }\end{array}$ & 4.24 & $\mathrm{~A}$ & 3.98 & $\mathrm{~A}$ \\
\hline Average weighted mean & 3.93 & $\mathrm{~A}$ & 3.96 & $\mathrm{~A}$ \\
\hline \hline
\end{tabular}

As shown in table 6, the general weighted mean of 3.93 from the community sector is nearer to 4 than 3 while the general weighted mean of 3.96 from the industry sector is also nearer to 4 than 3 . Both sectors accepted the statements under the Employability factor.
The $\mathrm{K}+12$, further states and ensure that the students graduating at the age of 18 will have jobs, thus making them "employable" even without a college degree [4]. It is good to know that both sectors, the community and the industry accepted the facts that the $\mathrm{K}+12$ program will help to equip the skills, training and competencies of the stud

\section{Conclusion}

This study will help the Department of Education and the government in the promotion and inclusion of which technical-vocational courses to offer in the province of Bulacan, specifically in the covered areas of study.

\section{REFERENCES}

[1] Bigcas, J. (2016) A Mini Critique of K-12 Basic Education Curriculum Retrieved from https://www.researchgate.net/ publication/305388829 K12 Basic Education Curriculum

[2] Estacio, Melanie P. (2015), All Set for $K$ to 12 Implementation- Republic of the Philippines- Department of Education Retrieved from http://www.deped.gov.ph/regions/ region-xi/regional-press-releases/all-set-k-12-implementation

[3] Journal of Information Systems, Volume 26, Number 1, USA. Spring 2012

[4] Maramag, S. K. Proposed K12 Basic Education System in the Philippines, Is the K-12 model good for the Philippine Education System?, via Philippine Online Chronicles.

Retrived from http://blogwatch. tv/2011/05/proposed-k-12basic-education-systemin-the-philippines/(Accessed 10 March 2012).

[5] http://www.gov.ph/k-12/

[6] http://wwwl.up.edu.ph/index.php/up-gears-up-for-the-impact -of-the-k-12-curriculum-and-asean-economic-cooperation2015/

[7] www.depedregion6.ph/

[8] http://en.wikipedia.org/wiki/K\%E2\%80\%9312\% 28 education $\% 29$ 